\title{
Market Participation of Smallholder Sunflower Farmers in Sekhukhune District of Limpopo Province, South Africa
}

\author{
HT Mathagu ${ }^{1}$, A Belete ${ }^{1}$, IB Oluwatayo ${ }^{1 *}$ and AE Nesamvuni ${ }^{2}$ \\ ${ }^{1}$ Department of Animal Production and Agricultural Economics, University of Limpopo, South Africa \\ ${ }^{2}$ University of Venda, School of Agriculture, South Africa
}

Submission: February 09, 2018; Published: March 29, 2018

"Corresponding author: IB Oluwatayo, Department of Animal Production and Agricultural Economics, University of Limpopo, Sovenga 0727, South Africa, Email: isaac.oluwatayo@ul.ac.za

\begin{abstract}
Sunflower has a broad value chain, which makes it an important crop in South Africa's agribusiness sector. The purpose of this study is to examine market participation among smallholder sunflower farmers of Sekhukhune District, Limpopo Province South Africa. To analyse data logistic Regression Model was used. The objectives of the study were to analyse the socio-economic factors that affect market participation of smallholder sunflower farmers in Sekhukhune District and to determine the constraints faced by these farmers. Results of the logistic regression model employed showed that farm size, stakeholder availability, distance from the market and farm size were significant variables influencing market participation in the study area. The study showed variables that influence market participation of smallholder sunflower farmers. The data was obtained from a sample of 100 participants randomly selected from a population of 145 of which $63.3 \%$ were male headed and $36.7 \%$ were female headed sunflower farmers, socioeconomic analysis of respondents indicated that factors that were very significant in influencing farmer's participation in market were: farm size, stakeholder availability and distance from the market at $5 \%$ level of significance and farm size at $10 \%$ level of significance.
\end{abstract}

Keywords: Smallholder farmers; Sekhukhune; Logistic regression model; Sunflower

\section{Introduction}

There is no gainsaying the fact that studies on smallholder farmers' participation have been conducted on a number of agricultural commodities especially in agrarian societies like Africa. This is not unconnected with the prime place of market access in the lives of poor households especially those relying on income generated from crop or animal sales for household upkeep [1,2]. According to Goetz [3], most of the studies focused on the role of transaction cost and market failure on smallholder farmers' decision to participate in market. While in small or less developed markets, it is difficult to identify market opportunities, poor market access increases households' transaction cost and decision to participate through high transportation cost and the distance covered to market their produce.

According to the Strategic Plan for South African Agriculture DOA [4], there are approximately 240000 black farmers in South Africa who provide a livelihood for more than a million of their family members, and provide temporary employment

for another 500000 people. According to Baloyi [5], agriculture is a very important sector in Limpopo province because of its provision of food, contribution to the economy and creation of employment for the people. This is an indication that agriculture plays a huge role in the food security and livelihoods of farmers, farm workers and their families.

Sekhukhune District comprises of both commercial and smallholder farmers who produce sunflower, though the commercial farmers of sunflower hold a larger percentage of producing and also participating in the markets compared to the smallholder farmers of sunflower. Sunflower is said to be the most important oil crop in South Africa [6]. The sunflower seed can be processed into oil, such oil can be refined into different products, animal feed and bio-diesel. The aim of the study was to examine the determinants of market participation among smallholder sunflower farmers in Sekhukhune District of Limpopo Province, South Africa.

\section{Materials and Method}

\section{Study area}

The study was conducted in Sekhukhune District of Limpopo province (Figure 1), where smallholder sunflower farmers in the District were interviewed. Sekhukhune District was once said 
to be located between Mpumalanga and Limpopo province, but now it is entirely located in the Limpopo province. The District is situated $200 \mathrm{~km}$ North of Pretoria, $150 \mathrm{~km}$ West of Nelspruit and $120 \mathrm{~km}$ South of Polokwane.

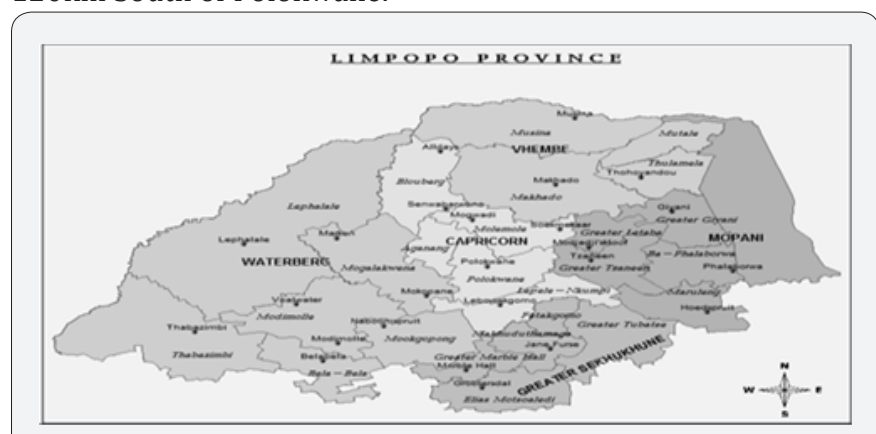

Figure 1: Map of Limpopo Province showing Sekhukhune District.

According to the Final 2012/13 IDP Report, Sekhukhune

District is one of the five Districts that are found in the Limpopo province,that is Capricorn, Mopani, Vhembe, and Waterberg District. Sekhukhune District has five Municipalities, which are Tubatse, Makhuduthamaga, Groblersdal, Marble Hall, and Fetakgomo, (Sekhukhune Nodal Economic Development Profile, 2005). Below is a map of Limpopo Province, one of the nine provinces of South Africa.

\section{Data sources and sampling method}

The study used random sampling, whereby each member of the population had an equal chance of being included in the sample, Bless \& Higson [7]. Out of a population of 165 smallholder sunflower farmers Sekhukhune, a sample of 100 was randomly selected. A data base from the Department of Agriculture in Sekhukhune District containing all the names of the smallholder sunflower farmers was used. The study used of primary and secondary data. The primary data was collected through the use of questionnaires. The study involved the use of semi-structured in-depth questionnaire with both open-ended and closed-ended questions, Tashakkori \& Teddlie [8]. To measure the probability that farmers participate in markets, a Logistic Regression Model was run using the Statistical Package for Social Sciences (SPSS 26.0).

\section{Analytical methods}

Both descriptive statistics and logistic regression models were employed in the study. While the former was used to analyse and describe respondents' socioeconomic characteristics, the latter was employed to ascertain the determinants of market participation among the smallholder sunflower farmers. For the logistic model, according to Meliko \& Oni [9] Logistic regression model was used in the prediction of a dichotomous outcome, because the dependent variable is not continuous, it takes the value 0 or 1 . Log it model makes no assumption about the distribution of the independent variable; therefore, the independent variables in Log it model can take any form. According to Archera \& Lemeshow [10], Logistic regression model is used to estimate the effect that the behavioural and risk factor variables have on a dichotomous outcome, such as market participation, that is participating in markets or not participating in markets. Logistic regression model was used to test the first hypothesis of the study, the model allowed the researcher to analyze the socio-economic variables that affect market participation of the smallholder sunflower farmers of Sekhukhune District and for the second hypothesis descriptive statistics was used. The dependent variable was market participation and the independent variables were age, gender, level of education, household size, income, distance to market, stakeholder availability, ownership of vehicle, land tenure, market information, price of sunflower, training, credit access, market experience and tons produced. To estimate the parameters of the Logistic Regression, model the SPSS 26.0 software package was used in the study.

The Logistic regression model is expressed as follows:

$$
\operatorname{Logit}(P)=\operatorname{In}(\underline{p})=\beta_{0}+\beta_{i} X_{2}+\ldots \ldots+\beta_{n} X_{n} \quad 1
$$

\section{1- P}

Where by $\beta_{0}=$ Coefficients,

\section{$\beta_{i}=$ Regression coefficient of $X$}

$n$ = Number of independent variables

$X=$ Independent variables

$P=$ Probability ( $\mathrm{Y}=1)$, whereby the value of $\mathrm{P}$ is calculated by taking the inverse of the $\operatorname{Logit}(P)$.

The empirical Logistic Regression model that analysed market participation of the smallholder sunflower farmers in the study was expressed as follows:

Logit $[p /(1 p)] P)=\beta_{0}+\beta_{1} X_{1}+\beta_{2} X_{2}+\beta_{3} X_{3} \ldots \ldots+\beta_{n} X_{n} 2$

$P(Y i=1 \mid x i)=$ the probability that smallholder sunflower farmers participate in markets or not, if they participate then $\mathrm{Y}=1$ if not, then $\mathrm{Y}=0$.

\section{$Y i=$ market participation}

$$
B i=\text { regression coefficient of } X
$$

$X_{1}=$ age, $X_{2}=$ gender, $X_{3}=$ level of education, $X_{4}=$ Household size, $X_{5}=$ Income, $X_{6}=$ Distance to market, $X_{7}=$ Stakeholder availability, $X_{8}=$ Ownership of vehicle, $X_{9}=$ Land tenure, $X_{10}=$ Market information, $X_{11}=$ Price of sunflower, $X_{12}=$ Training, $X_{13}=$ Credit access, $X_{14}=$ Market experience, $X_{15}=$ Tons produced

$X$ or $\operatorname{Pr}(Y i=1 \mid x i)=$ the model parameters to be estimated.

Market participation $(Y)=1$ if smallholder farmers participate in markets,

Market participation $(Y)=0$ if otherwise

\section{Results and Discussion}

The Logistic Regression model analyzed market participation of the smallholder sunflower farmers of Sekhukhune District. 
The independent variables were: age of household head, gender of household head, household size, level of education, income, distance to the market, market information, price of sunflower, credit access, marketing experience, tons produced training, stakeholder availability, land tenure arrangements and ownership of vehicles. For the first objective descriptive analysis technique was used in the study to analyse the responses from the smallholder sunflower farmers of Sekhukhune District and for the second objective the Logistic Regression model was used to analyse.

\section{Logistic regression results on determinants of market participation}

In this section, the results of the test for significance and non-significance of the determinants of market participation of the smallholder sunflower farmers are presented in Table 1 below. The table displays the socio-economic variables that affect market participation of smallholder sunflower farmers. The table estimated results for the logistic regression model and also explained the socio-economic factors which were tested using the Logistic Regression Model. Table 1 below shows the variables. The Pseudo R2 was 50.1\%. 3 variables on market participation of smallholder sunflower farmers were found to be positively significant. The variables were: farm size, stakeholder availability, and distance to market. The variables, distance to the market and ownership of vehicle have a significant negative influence on the participation of the smallholder sunflower farmers in the markets. The results are represented below:

Table 1: A table showing how the above variables were measured.

\begin{tabular}{|c|c|c|c|}
\hline Variables & Description & Unit Measurement & Expected Signs \\
\hline \multicolumn{4}{|c|}{ Dependent Variable } \\
\hline Market Participation & 1 if the household head participates in markets, 0 if otherwise & Dummy & \\
\hline \multicolumn{4}{|c|}{ Independent Variables } \\
\hline Age of household head & Number of years & Years & - \\
\hline Gender of Household head & 1 if the household head is female, 0 if otherwise & Dummy & \pm \\
\hline Level of education & 1 if the household head has passed grade 12,0 if otherwise & Dummy & \pm \\
\hline Household size & Household size number & Number & + \\
\hline Income & 1 if the household head has a source of income, 0 if otherwise & Dummy & \pm \\
\hline Distance to the market & $\begin{array}{c}1 \text { if the distance to the market affects market participation, } 0 \text { if } \\
\text { otherwise }\end{array}$ & Dummy & \pm \\
\hline Stakeholder Availability & 1 if there is availability of stakeholders, 0 if otherwise & Dummy & \pm \\
\hline Ownership of Vehicle & 1 if household head owns vehicles, 0 if otherwise & Dummy & \pm \\
\hline Land Tenure arrangement & $\begin{array}{c}1 \text { if household head is the legal owner of the production land, } 0 \text { if } \\
\text { otherwise }\end{array}$ & Dummy & \pm \\
\hline Market Information & 1 if information on markets affects market participation, 0 if otherwise & Dummy & \pm \\
\hline Price of Sunflower & Price of sunflower in the market & Rand & - \\
\hline Training Availability & 1 if household head receives training, 0 if otherwise & Dummy & \pm \\
\hline Credit Access & 1 if household head has access to credit, 0 if otherwise & Dummy & \pm \\
\hline Market Experience & 1 if household head has market experience, 0 if otherwise & Dummy & \pm \\
\hline Tons produced & Number of tons produced & Tons & + \\
\hline
\end{tabular}

Source: Computed from survey data.

\section{Hypothesis testing and model fitness}

Archera \& Lemeshow [10] continued to say that when using the Logistic regression model the goodness of fit should also be examined especially if the purpose of the model is to estimate probabilities of an event occurring given that the observations selected are independent. The Chi-square analysis was used to measure the goodness of fit, where it will show differences between the expected results and the actual results, where it will determine if the actual/ observed frequency matches the expected/ theoretical frequency at a significance level that will be set at 0.05 . The model chi-squared at 38.5 indicates the significant rating of $1 \%$ level, meaning that there is a significant relationship between the independent variables and the dependent variable. The main assumption for the $-2 \log$ likelihood ratio is that there are socio-economic characteristics that influence market participation of smallholder sunflower farmers in Sekhukhune District. The log likelihood ratio of 99.326 in Table 2 above indicates that there are socio-economic characteristics that influence market participation. Therefore, the null hypothesis which reveals that there are no socioeconomic characteristics that influence market participation by smallholder sunflower farmers in Sekhukhune District is rejected. The model is correctly predicted at $72.1 \%$. This implies that $27.9 \%$ of the variables are insignificant but are included in the final analysis, which explains the relationship between the dependent and explanatory variables. Next, the variables which were found to be significant in the model were explained. 


\section{Agricultural Research \& Technology: Open Access Journal}

Table 2: Socio-economic variables affecting market participation of smallholder sunflower farmers.

\begin{tabular}{|c|c|c|c|c|}
\hline Variables & Coefficient & Standard error & Wald significance & Significance level \\
\hline Age & $-0.0151 \mathrm{~ns}$ & 0.027 & 0.269 & 0.604 \\
\hline Farm size & $0.174^{* *}$ & 0.076 & 5.258 & 0.022 \\
\hline Education & $0.124 \mathrm{~ns}$ & 0.518 & 0.057 & 0.811 \\
\hline Gender & $-0.915 n s$ & 0.665 & 1.896 & 0.169 \\
\hline Market Exp & $0.752 \mathrm{~ns}$ & 0.327 & 1.008 & 0.315 \\
\hline Stakehol Avail & $2.468^{* *}$ & 1.219 & 3.907 & 0.048 \\
\hline Distance Mrkt & $-3.161^{* *}$ & 1.585 & 3.977 & 0.046 \\
\hline Own Vehicle & $-0.107 n s$ & 0.07 & 0.871 & 0.112 \\
\hline Constant & $5.604^{*}$ & 3.505 & 2.557 & 0.11 \\
\hline-2 log likelihood & \multicolumn{4}{|c|}{99.326} \\
\hline R squared & \multicolumn{4}{|c|}{$50.10 \%$} \\
\hline$\%$ cases correctly predicted & \multicolumn{4}{|c|}{$72.10 \%$} \\
\hline Chi-squared & \multicolumn{4}{|c|}{38.5} \\
\hline
\end{tabular}

$*$ **, ${ }^{* * *}$ Significant at $10 \%, 5 \%$, and $1 \%$ respectively

ns - Not Significant at $0.604,0.811,0.315,0.112$ and 0.169

Source: Computed from survey data

Age

The age coefficient of smallholder sunflower farmers in the study area was negative and statistically non-significant. The results of the analytical model indicate that the age of the household head does not affect the probability that smallholder sunflower farmers of Sekhukhune District of Limpopo participate in markets.

\section{Farm size}

The variable farm size is positively significant at $5 \%$ level, which tends to be one of the most significant variables found. The implication is that there is a positive relationship between farm size and smallholder farmers' market participation. This shows that the farm size affects the probability that the smallholder sunflower farmers participate in markets. Land plays an important role in farming in terms of productivity given that enough supporting inputs are available. This implies that if these farmers produce more sunflower they will be able to participate more in marketing to avoid surplus. According to Raghbendra et al. [11], there is a positive correlation between land size and production level in smallholder agriculture, which may lead to increased market participation. Gender of household head. The estimated gender dummy coefficient was found to be negative and not significant as expected. This indicated that males are dominant in market participation compared to their female counterparts. This could also be explained by the fact that in most rural farming communities, men are the ones who mostly engaged in agricultural activities while female counterparts engage in off-farm activities.

\section{Distance to the nearest market}

The coefficient of distance to the nearest market was found to be negative and significant at $5 \%$. This implies that the level of market participation of smallholder sunflower farmers is negatively influenced by the distance from the market. It indicates that the probability of smallholder sunflower farmers participating in markets is not affected by the distance to the market. Some of the farmers also indicated that they do not own the transports that take their products to the market.

\section{Stakeholders available}

The coefficient of stakeholder availability is significant at $5 \%$ and positive, this indicates that stakeholders in the form of middlemen are important in the marketing of smallholder sunflower famer in the study area and that shows that the probability of smallholder sunflower farmers participating in markets is affected by the availability of stakeholders. Most smallholder farmers also supported this result by indicating that without a marketing agent they would not be able to market their crops since they do not have enough marketing information.

\section{Constraints facing smallholder sunflower farmers}

One of the main challenges facing smallholder sunflower farmers is lack of direct linkage between farmers and consumers. The smallholder sunflower farmers do not usually get the prices they are expecting in the markets and this is considered as a severe constraint. Abedullah \& Bukhsh [12], reported that marketing system still remained in traditional and heterogeneous condition in smallholder farming, as a result, producers could not develop direct linkages with the consumers, instead they utilise middlemen. Some respondents indicated that they do not have enough financial resources to access better and broader markets and also the lack of proper infrastructure, lack of knowledge on how to introduce a product to the market. The smallholder sunflower farmers feel their customers perceive their products as poor or of low quality this might be due to the fact that smallholder farmers might be lacking sunflower storage infrastructure. 


\section{Conclusion and Recommendations}

The study had two research objectives, namely to; determine socio-economic characteristics of smallholder sunflower farmers in the Sekhukhune district of Limpopo Province and determine the constraints faced by the smallholder sunflower farmers in the study area. The results of the analysis showed that there are socio-economic characteristics that affect market participation of smallholder sunflower farmers in Sekhukhune District. On the second objective, wherein it was investigating constraints that are faced by farmers in participating in markets in the study area. In support to this objective, results indicated that there were constraints affecting farmers from participating in markets.

Based on the study findings and considering the significant variables from the model results, several recommendations were drawn.

A. The study suggests ways in which market participation in formal markets by smallholder farmers can be improved and the value of Sunflower marketed in formal markets increased. The study gave rise to some important recommendations with regard to market participation of smallholder sunflower farmers in South Africa. The following recommendations will help to address some of the challenges that smallholder sunflower farmers are facing:

B. Access to production land: Farm sizes and access to land in general play an important role in farm income; and successful participation of smallholder sunflower farmers in agricultural markets. The results of the study clearly indicated the need for increased land for farming. In addition, tenure security in which farmers had user rights and did not own the land they farmed on negatively influenced their decision to participate in the formal markets.

C. It was also highlighted in this study that labour employed on the farm increased the value of Sunflower marketed in the formal markets. According to Moloi [13], the size of the farm enterprise is directly related to employment of labour. If the farm size is big and the household labour is not able to handle the farming activities, the employment of labour is necessary for income generation.

D. Stakeholder availability and involvement: Farmer Organisations such as NAFU (National African Farmers Union) provide a wide range of services such as financial services, training, advisory services, skill development, and represent their members' interests in expressing demand for service. Therefore, farmer organisations can be a solution to most market related problems encountered by sunflower smallholder farmers in Sekhukhune District.

E. Farmers should also be mobilized and encouraged to form farmer groups. The government should seek to coordinate such training by subsidizing universities and colleges for the benefit of smallholder farmers. Furthermore, farmers are continuously confronted with new technology. Various training techniques can be applied for farmers who are illiterate in order for them to keep up with market changes. Commodity-based policies should also be implemented in South Africa's agriculture [14-20].

\section{Acknowledgement}

The study was done on market access of the smallholder sunflower farmers in Sekhukhune District of Limpopo Province in South Africa under the University of Limpopo. We also acknowledge the University of Venda for the support with the data collection.

\section{References}

1. IFAD-IFPRI (2012) Agricultural Commercialisation in Northern Ghana: Innovation Policies on Increasing Access to Market for High- Value Commodities and Climate Change Mitigation. IFAD-IFPRI Partnership Newsletter.

2. Olwande J, Mathenge M (2012) Market Participation among Poor Rural Households in Kenya: In Paper Presented at the International Association of Agricultural Economists Triennial Conference. Brazil.

3. Goetz SJ (1992) A selectivity Model of Households Food Market Behaviour in Sub-Saharan Africa. American Journal of Agricultural Economics 74(2): 444-452.

4. DOA (2001) Strategic Plan for South African Agriculture. Pretoria: Department of Agriculture.

5. Baloyi JK (2010) An analysis of constraints facing smallholder farmers in Agribusiness value chain: A case study of farmers in the Limpopo Province. MSc University of Pretoria.

6. Van Zyl ICJ (2010) Capturing the Dynamics of the South African Sunflower Seed Market in a Partial Equilibrium Market. M.Sc. University of Pretoria.

7. Bless C, Higson-Smith C (1995) Fundamentals of social research methods: an African perspective. ( $2^{\text {nd }}$ edn), Juta \& Co Ltd, Kenwyn, South Africa.

8. Tashakkori A, Teddie C (2003) Handbook of mixed methods in social and behavioural research. Thousand Oaks, Sage, USA.

9. Meliko MO, Oni AS (2011) Effect of Irrigation on Poverty among Small-Scale Farmers in Limpopo Province of South Africa. Journal of Agricultural Science 3(3).

10. Archera KJ, Lemeshow S (2006) Goodness-of-fit test for a logistic regression model estimated using survey sample data. The Stata J 6(1): 97-105.

11. Raghbendra Jha, Hari K Nagarajan, Subbarayan P (2005) Land Fragmentation and its Implications for Productivity: Evidence from Southern India. Australia South Asia Research Centre (ASARC) Working Paper 2005/01.

12. Abedullah AM, Bukhsh K (2007) Issues and Economics of Poultry Production: A case study of Faisalabab, Pakistan. Pakistan Vet J 27(1): 25-28.

13. Moloi MJ (2008) A Comparison of Socio-economic characteristics that determine the farm income of Emerging Livestock and Horticultural Framers in South Africa. MSc University of Limpopo.

14. DPLG (2005) Sekhukhune Nodal Development Profile. Limpopo Province, South Africa.

15. Esterhuizen (2006) Defining the competitive environment for the South African Agribusiness sector. PhD. University of Pretoria. 
16. IDP (Integrated Development Planning) (2010/11) IDP Budget. Capricorn District Municipality.

17. IDP (Integrated Development Planning. (2012/13) Waterberg District Municipality.

18. Porter ME (1998) The Competitive advantage of nations: with a new introduction. Palgrave, Houndmills, Basingstoke publishing, New York, USA.

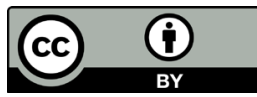

This work is licensed under Creative Commons Attribution 4.0 License

DOI: 10.19080/AROAJ.2018.15.555938
19. Porter ME (1990) The competitive advantage of nations. Free Press, MacMillan, New York, USA.

20. Smit AJ (2010) The competitive advantage of nations: is Porter's Diamond Framework a new theory that explains the international competitiveness of countries. Graduate School of Business Leadership, Southern African Business Review Volume 14(1). University of South Africa.

Your next submission with Juniper Publishers will reach you the below assets

- Quality Editorial service

- Swift Peer Review

- Reprints availability

- E-prints Service

- Manuscript Podcast for convenient understanding

- Global attainment for your research

- Manuscript accessibility in different formats ( Pdf, E-pub, Full Text, Audio)

- Unceasing customer service

Track the below URL for one-step submission https://juniperpublishers.com/online-submission.php 